\title{
LEGAL REGULATION OF LIABILITY FOR OFFENSES IN THE FINANCIAL SPHERE IN THE EU COUNTRIES AND UKRAINE: COMPARATIVE ANALYSIS
}

\author{
Dmytro Pryimachenko ${ }^{1}$, Tetiana Minka ${ }^{2}$, Volodymyr Marchenko³
}

\begin{abstract}
The aim of the article is to conduct a comparative analysis of the legal principles for liability in the financial sphere in the EU and Ukraine and to define ways of domestic legislation improvement on this basis. The subject of the study is the experience of European countries in the state regulation of liability for financial offenses. Methodology. The study is based on a comparison of foreign experience in the legal regulation of liability for financial offenses on the example of European states with the status of the national tort law in this area. The use of general scientific and special scientific methods and techniques of scientific knowledge enabled to characterize the national experience of the legal regulation of legal liability for committing financial offenses by the coverage of the provisions of the Criminal Code of Ukraine, the Code of Ukraine on Administrative Offenses, and the Tax Code of Ukraine, as well as its comparison with the experience of the legal regulation of liability for offenses in the financial sector on the example of France, Germany, Latvia, Spain, Sweden, Greece, and other EU countries. The results of the comparative legal study revealed that contrasting the EU member states, the national model of the legal regulation of liability for offenses in the financial sector is characterized by multi-levelness and varying degree of severity of punishment. Practical implications. It is proved that the mechanism of the legal regulation of liability for financial offenses in Ukraine is more improved than in European countries because of the legal provisions with a strict codification of financial offenses, their differentiation into administrative delicts and criminal offenses that enables to impose milder state sanctions on those acts that do not pose a significant social danger. Relevance/originality. A comparative legal study of the experience of the legal regulation of liability for financial offenses provides a better understanding of the prospects for the development of national administrative tort law in this area.
\end{abstract}

Key words: legal liability, financial offenses, legal regulation.

JEL Classification: G17, 016, P34

\section{Introduction}

Violation of a stable social order always has a negative undertone whatever the intensity of such violation and severity of its consequences are. This aspect is particularly acute in the twenty first century when society is expanding its sphere of existence and the number of objects of influence and research. One of the most important areas of human life is financial since it involves the interests of all social formations, from individual to the entire state. Moreover, the financial sector is important because it involves relations associated with material values, more often with high volumes of funds, which are financial resources in totality. Without accurate managing and using the latter, any state will not be able to function properly; moreover, violated financial relations lead to disorder in a country. Therefore, for the protection of financial relations, legal regulations that form the mechanism of liability for their violation are developed and adopted.

\footnotetext{
Corresponding author:

${ }^{1}$ University of Customs and Finance, Ukraine.

${ }^{2}$ University of Customs and Finance, Ukraine.

${ }^{3}$ H.S. Skovoroda Kharkiv National Pedagogical University, Ukraine.
}

Furthermore, for the improvement of the legal regulation of liability for offenses in the financial sector, these issues require both scientific development and analysis of the foreign experience of European states. According to P.S. Melnyk, foreign experience contributes to expanding our perceptions of the legal phenomena under the study; helps consider this or that problem from another angle, compare own achievements with the achievements of foreign colleagues; prevents wasting time to solve problems that have already found solutions in foreign publications. In addition, the extraordinary scientific relevance and practical utility of any comparative legal research are undeniable (Melnyk, 2010). Therefore, to highlight the positive aspects of the national system of legal regulation of liability for offenses in the financial sphere, as well as issues that need improvement in this regard, it is necessary to conduct a comparative analysis of the foreign experience of the EU and Ukraine on this issue. 
The theoretical basis of this study is the achievements of many academic scholars in scientific research on various aspects of liability for offenses committed in the financial area, in particular, S. V. Kivalov, Z. M. Budko, A. Y. Ivanovskyi, I. Y. Slubskyi, Yu. P. Bytiak, A. T. Komziuk, M. I. Melnyk, V. K. Kolpakov, T. M. Yamnenko, A. M. Bandurka, A. M. Klochko, R. S. Satuev, V. M. Popovych and others.

\section{Main material}

To begin with, a comparative analysis requires defining the concept of "responsibility" and "offense". It should be noted that the etymology of the word "responsibility" means the obligation imposed on someone or taken on oneself to be responsible for a certain area of work, a case, for someone's actions, deeds, words, leading to taking guilt for possible negative consequences (Busel, 2005; Slovar russkogo literaturnogo yazyka).

It should be noted that the term "responsibility" is the subject of the study of many sciences that confirms its multidimensionality and significance for various aspects of social reality. Philosophy studies responsibility as a concept that reflects the objective, historically specified nature of the relations between a person, a collectivity, and society from the perspective of conscious implementation of mutual requirements (Illicheva, Fedoseev, (Eds.), 1983; Popov, 2001).

In the legal sphere, responsibility acquires the meaning of legal responsibility/liability and is interpreted as a form of social responsibility, the core of which is state enforcement of the sanctions provided by the law to the offenders (individuals and legal entities). Legal responsibility is a legal relationship between the state represented by the authorities and the offender, subject to legal sanctions with negative consequences for him/ her (Shemshuchenko, 1998).

Therefore, liability is negative state response, based on the relevant prohibitive legal regulations, to the offenses committed in relation to a particular object (legal relations in a specific sphere of public life), which gives a motivated right to apply methods of state coercion.

In this case, the "key" to the occurrence of legal responsibility is the offense. According to the reference literature, to offend (to violate) means:

1) to do something contrary to the order, the law and so on; 2) to act, to do contrary to norms, customs, generally accepted rules, to deviate from something established, customary;

3) to recite anything wrongly, distort, misrepresent;

4) to interfere, interrupt any state, process or feeling;

5) to damage, destruct, destroy anything;

6) to start;

7) to cause, awaken something, set in motion, move something from the place;

8) to touch, take without permission something, and so on (Bilodid, 1976).
The offense has a wider meaning. For example, O. F. Skakun defines the offense as a public hazardous or harmfully unlawful (wrongful) culpable act (action or inaction) of a delictual person, which entails liability (Skakun, 2010).V.P. Marchuk characterizes the offense as an unlawful, culpable act, individually or socially harmful or dangerous, by a delictual subject (Marchuk, (Ed.), 2003). K. H. Volynka notes that the offense is a social and legal opposite of lawful conduct. Such behaviour violates the rights and interests of either individuals or society as a whole. In total, offenses constitute a danger to society, violate the rule of law, the existing legal order (Volynka, 2003; Podorozhnii, 2016).

In this regard, M.M. Marchenko argues that in any society, the offense is a social and legal antipode of lawful conduct. There are many different definitions of an offense. In general, they can be summarized by saying that the offense is a culpable, unlawful, socially harmful act of a legally capable person or persons, which entails legal liability (Bedniakova, 2006; Marchenko, 2004; Podorozhnii, 2016).

In accordance with this definition, an offense in the financial sphere is an unlawful, culpable act that violates the normal state of legal relationships arising from the fact of the management, distribution, coordination, use and other actions with financial resources. To be precise, this is the violation of certain regulatory provisions of the budget, tax, banking, currency, monetary and other types of legislation (Orliuk, 2010; Romaniuk, 2013).

It should be noted that in Ukraine, the specifics of legal regulation of liability for offenses in the financial sphere varies according to the sectoral distribution of such unlawful acts, which is based on the degree of social danger and the degree of punishability of the latter. In this context, offenses can be classified into administrative offenses in the financial sphere and criminal ones, that is, crimes.

Accordingly, legal responsibility for the actions of the first group is provided for in the Code of Ukraine on Administrative Offenses (hereinafter - the CAO), which shall protect the rights and freedoms of citizens, property, the constitutional system of Ukraine, the rights and legitimate interests of enterprises, institutions and organizations, established legal order, strengthen the rule of law, prevent offenses, educate citizens to consistently abide by the Constitution and laws of Ukraine, to respect the rights, honour and dignity of other citizens, the rules of civil coexistence and to honestly fulfil their duties, obligations to the society (Kodeks Ukrainy pro administratyvni pravoporushennia).

In particular, in Chapter 12 of Section II of the CAO, a number of legal regulations provide for liability for offenses in the financial sphere, such as:

- Article 162 of the CAO: the illegal purchase, sale, exchange, use of currency values as a means of payment or as collateral - shall entail a warning or imposing a fine of thirty to forty-four times 
minimum non-taxable incomes with the confiscation of currency values;

- Article 1622 of the CAO: the illegal opening or use of foreign currency accounts of individuals, committed by a citizen of Ukraine residing permanently in its territory, as well as currency accounts of legal entities operating in Ukraine, committed by an official of the enterprise, institution or organization or on his/her behalf by another person, as well as the commission of the said actions by a citizen, an entrepreneur, - shall entail imposing a fine amounting to 500 to 1,000 times minimum non-taxable incomes;

- Article 1632 of the CAO: non-submission or untimely submission of payment orders by officials of enterprises, institutions, and organizations for the transfer of payable taxes and charges (mandatory payments) - shall entail imposing a fine on officials amounting to from five to ten times minimum non-taxable incomes;

- Article 1634 of the CAO: failure to deduct or failure to transfer to the budget the sum of the tax on personal income in the payment of income to a natural person, transfer of personal income tax at the expense of enterprises, institutions, and organizations (except when such transfer is permitted by law); failure to notify or late notification on the incomes of citizens to the state tax inspectorates on the agreed format - shall entail a warning or imposing a fine on officials of enterprises, institutions, and organizations, as well as on citizens, entrepreneurs, of two to three times minimum nontaxable incomes;

- Article 1638 of the CAO: deliberate actions of an official participant in the stock market bearing marks of manipulation on the stock market, established in accordance with the law on state regulation of the securities market, - shall entail imposing a fine of one hundred to five hundred times minimum non-taxable incomes;

- Article 16313 of the CAO: violation of laws of Ukraine and regulatory acts of the National Bank of Ukraine regarding the procedure for accepting cash for its further transfer by a non-bank financial institution which is licensed by the National Bank of Ukraine for transferring funds without opening accounts, a commercial bank agent - shall entail imposing a fine on officials of a non-bank financial institution licensed by the National Bank of Ukraine for transferring funds without opening accounts, a commercial bank agent of one hundred to two hundred times minimum nontaxable incomes;

- Article 16314 of the CAO: violation of the laws of Ukraine and regulatory acts of the National Bank of Ukraine regarding the procedure for the transactions with electronic money - shall entail imposing a fine on officials of a legal entity, a business entity, of one hundred to two hundred times minimum non-taxable incomes, and others (Kodeks Ukrainy pro administratyvni pravoporushennia).
Specific offenses in the financial sphere, namely in taxation, and the specificities of the occurrence of liability for their commission are regulated by the Articles of the Tax Code of Ukraine (hereinafter the TCU). In addition, this specified legal regulation controls a special type of liability, that is, financial. In accordance with Article 11 of the TCU, financial liability for violating laws on taxation and other legislation is established and applied in compliance with the TCU and other laws. A financial liability is (financial) fines and/or penalties (Podatkovyi kodeks Ukrainy).

The specified type of liability is applied in case of committing offenses directly stipulated by the provisions of the TCU, such as:

- Article 117 of the TCU: non-submission, within the time limits and in cases provided for by the TCU, applications or documents for registration in the relevant controlling body, registration of changes in the location or other changes to their credentials, nonsubmission of corrected documents for registration or amendment, misrepresentation or incomplete submission, nonsubmission of information on persons responsible for accounting and/or drawing up tax reports in accordance with requirements of the TCU, shall entail imposing a fine on self-employed persons up to 170 hryvnias, on legal entities, separate units of a legal entity or legal entity responsible for charging and paying taxes to the budget while performing the agreement on joint activity, up to 510 hryvnias;

- Article 118 of the TCU: non-submission of information on the opening or closing of accounts of taxpayers to the relevant supervisory authorities within the established term by banks or other financial institutions - shall entail a fine of 340 hryvnias for each case of non-submission or delay;

- Article 126 of the TCU: if the taxpayer does not pay the agreed amount of monetary obligation within the timeframe prescribed by law, such taxpayer is liable to a fine, etc. (Podatkovyi kodeks Ukrainy).

The next group of offenses is crimes, that is, socially dangerous culpable acts, which entail a criminal liability (Kryminalnyi kodeks Ukrainy). A key feature of criminal offenses is a significant degree of their public danger, in other words, the high level of harm inflicted on society in connection with their commission. This factor determines much more severe legal responsibility for this type of offense than for administrative ones.

The list of criminal acts in the financial sphere and certain aspects of liability for them are presented in the provisions of the Criminal Code of Ukraine (hereinafter - the CCU). Thus, a vivid example of a financial crime is the legalization of proceeds from crime, as provided for in Article 209 of the CCU, that is, the commission of a financial transaction or transaction involving monetary or other assets gained from the commission of a socially dangerous unlawful act preceding the legalization (laundering) of proceeds, 
as well as the commission of actions aimed at concealing or disguising the illegal origin of such monetary or other assets or possession thereof, rights to such monetary or other assets, sources of their origin, location, movement, change in their form (conversion), as well as acquisition, possession or use of monetary or other assets gained from the commission of a socially dangerous unlawful act preceding the legalization (laundering) of proceeds. Liability for such an act shall be the restraint of liberty for a term of three to six years with the deprivation of the right to occupy certain positions or engage in certain activities for up to two years with forfeiture of property (Kryminalnyi kodeks Ukrainy).

Furthermore, Article 210 of the Criminal Code provides for liability for use of budget funds contrary to their target allocation, budget expenditures or granting of credits from the budget without established budget appropriations or exceeding approved expenditure limits; as well as Article 211 provides for liability for publication of legal regulations that reduce budget revenues or increase budget expenditures contrary to the law. Liability for the latter act shall be an imposition of a fine of hundred to four hundred times minimum non-taxable incomes or corrective labour for a term up to two years, restraint of liberty for a term up to five years with the deprivation of the right to occupy certain positions or engage in certain activities for up to three years (Kryminalnyi kodeks Ukrainy).

Therefore, the national model of legal regulation of liability for offenses in the financial sector is characterized by multi-levelness and varying degrees of severity of punishment. However, in foreign countries, such as the states of the European Union, this issue is considered from a somewhat different angle.

For example, the analysis of Germany's experience as one of the most financially progressive countries to date enables to conclude that the legal system of this country is characterized by the division of offenses in total. In particular, one of the types of punishable criminal acts is an administrative offense (administrative delinquency). However, the regulation of liability for them is not separated from the general provisions of criminal laws in comparison with Ukrainian experience.

For example, considering tax violations in the financial sphere, the Tax Code of Germany, promulgated on October 1, 2002 (the Fiscal Code of Germany) (Fiscal Code of Germany in the version promulgated on 1 October 2002), is the most important legislative act defining the liability for tax crimes and offenses. It is worth noting that the German Criminal Code practically does not contain rules on liability for tax crimes, with the exception of punishments for falsifying the signs of payment of customs duties and disclosure of tax secrecy (Romanko). In the second subparagraph of Section 369 of the Tax Code, based on the principle of "lex specialis derogat generali," in other words, the prevailing application has a special regulation of the Tax
Code, the issue of possible competition of the criminal law of the Tax Code and the Criminal Code of the Federal Republic of Germany is allowed.

In order to analyse the specificities of the delineation of crimes and offenses in Germany's tax legislation, it is necessary to define the valid concepts and features of the crimes in the country. The Criminal Code of the Federal Republic of Germany of November 13, 1998, provides for a formal definition of a crime. In accordance with Section 11 of this law, 'unlawful act' means an act that fulfils all the elements of a criminal provision (Kryminalnyi kodeks FRN). Unlawfulness is understood as an act contradicting to the legal order in general, that is, an act must involve the statutory structure of a criminal act or violation of public order (Yermolova, Serebrenikova, 2008; Vaskevich).

Most legislative acts in Germany are focused on the regulation of financial offenses related to money laundering. In particular, the provisions of the Money Laundering Act of 1993 established the legal basis for the national system for counteracting this group of offenses. In addition, this legal regulation defined the list of participants of the system of financial monitoring, outlined the scope of obligations of the subjects of financial monitoring, and provided for sanctions for failure to meet requirements for client identification, collection, storage, and transmission of information to controlling bodies (Gesetz uber das Aufspuren von Gewinnen aus schweren Straftaten - Geldwachegesetz; Symovian, 2011).

Furthermore, the provisions of the German Criminal Code convey legal regulation of liability for "money laundering." The most severe punishment for the specified offense is the restraint of liberty for a term of up to 10 years. However, in some confluence of circumstances, the punishment shall not be at all. Sanctions are not imposed if a person voluntarily reports to the relevant authorities about the crime. In addition to sanctions for the legalization of criminal incomes, the Code has established a list of crimes predicate to laundering. In accordance with Section 12 of the German Criminal Code, all legal offenses punishable by imprisonment for one year and more may be "precedes" of the legalization. Among the less serious crimes in this list are the following violations: bribe-taking, bribery, extortion, trafficking in persons, pimping, theft, misappropriation, fraud, forgery of documents, gambling without appropriate permits and a number of other offenses (Symovian, 2011).

Next, the experience of France regarding the legal regulation of liability for offenses in the financial sector is worth analysing. It should be noted that the unlawful acts in this state are classified into three types, such as crimes, misdemeanours, and felonies (Symovian, 2011).

Furthermore, the French system of legal regulations, provisions regulating liability for offenses in the financial sphere is quite extensive. Accordingly, in France, articles 
on criminal liability for tax evasion are contained in the Tax Code of 1950 (Articles 1727-1756). However, the Criminal Code of France of 1992 does not define elements of tax crimes (Kozochkin, 2001; Salkazanov, 2017).

The French Tax Code defines criminal offenses, as: non-submission of a declaration of income or a delay in its submission (Article 1728); provision of a knowingly false declaration (Article 1729); untimely payment of taxes (Articles 7130-7130 B); violation of the invoicing rules (Article 1737); failure to declare or pay tax in electronic form (Article 1738) and other misdemeanours. The breach of the above-mentioned regulations shall be punished by either fines or an increase in total tax payable (Salkazanov, 2017).

It should be noted that in France a number of specific legislative acts provide for liability for activities aimed at laundering the proceeds from committing drug-related crimes (Mezentseva, 2002; Romanko).

The institution of liability for financial offenses is quite active in Spain. For example, in the Criminal Code of this state, many articles impose sanctions on certain financial violations. In particular, in Spain, manipulative actions related to stock markets are severely punished. For example, if a person uses or provides information relevant for quoting any type of securities on an organized, official or recognized market and receives for oneself or a third party an economic benefit exceeding 65 million pesetas (or the corresponding amount in euros), or causes damage by the same amount, the punishment shall be imprisonment for a term of one to four years and a fine of three times profit that a person has obtained by assisted to obtain thereof. The subject of such an offense is a person who has become aware of information due to the performance of his professional activities, such as a professional participant in the stock market (Kryminalnyi kodeks Ispanii; Klochko, 2013).

In Spain, counterfeiting and tax evasion are also recognized as criminal offenses. Liability for the latter is stipulated in Article 305 of the Criminal Code of this state; according to it, the acts are punishable in case of damage to the State Treasury of the state, autonomy, local treasury via non-payment of taxes, deductions, receipts, or use of state funds derived from underpayment of taxes not received, deductions or amounts to be refunded, or unreasonably received money. In this case, there are some exceptions. For example, even if the total unpaid or illegally retained funds exceed 15 million pesetas (one of the main attributes of incrimination), an offender may be exempted from legal liability for the said actions in case of a regulation of his/her tax obligations, before being informed by the tax authorities about the start of the audit aimed at determining tax obligations, or in the absence of such an audit, before the public prosecutor's office (another public authority) submits a complaint or a statement against the said person or before the prosecutor's office or investigating judge carries out actions that will result in the formal beginning of the case (Kokorev, 2012).
Therefore, the analysis of many European countries reveals that mostly the legal responsibility for offenses in the financial sphere tends to impose criminal sanctions. In other words, financial offenses, regardless of the degree of their social danger, as well as the scope of punishment for their commission, are regulated by criminal legislation.

For example, similarly to Spain, Swedish law incriminates a professional stock market participant for an act of manipulating stock market prices. In this country, abuse, such as the dissemination of misleading information to influence the price of any property, including securities, is criminalized. Persons who occupy certain positions in the organizations involved in bidding on the stock market are among other subjects liable for such acts (Klochko, 2013). In the overwhelming majority, it is precisely criminal responsibility for other offenses in the financial sector in Sweden.

However, in some countries of Europe, financial offenses include such unlawful actions, analogues of which the legal system of our state does not contain. For example, the provisions of the Criminal Law of Greece establish the legal responsibility for insurance fraud. This act is distinguished as an offense in many criminal laws and in Russian pre-revolutionary legislation as well. The person is punishable, if in order to receive for him/herself or another person the insurance money for a movable or immovable asset, he/she creates the danger, against which the thing is insured, as well as a person, who similarly to obtain the sum insured, causes selfinflicted injury or enhances the consequences of bodily injury received as a result of an accident (Talan, 2007).

The Austrian legislation provides for legal liability for "careless bankruptcy" carried out by a debtor of several lenders who inadvertently causes his/her insolvency, or being aware of own insolvency involuntarily causes damage to all or part of his/her lenders by entering into a new debt, pays a debt, pledges property, untimely offers to appoint external management of the property, conclude an amicable agreement, open a competition, etc. (Talan, 2007).

The foreign experience in the legal regulation of liability for offenses in the financial sphere of the Republic of Latvia is worth analysing. It is of interest because of common features in the legal systems of our states due to previous membership in the Soviet Union of this country and Ukraine. For example, both in Latvia and in our country, a codified act establishes liability for administrative offenses, along with crimes, in particular in the financial sphere. The Code of the Republic of Latvia on Administrative Offenses recognizes as offenses following acts: non-compliance with procedures for registration of cash transactions, violation of consumer credit rules, tax evasion, false information in tax returns, etc., for which are liable to a fine (Kodeks Latvii pro administratyvni pravoporushennia).

A similar model of the legal regulation of liability for offenses in the financial sphere is currently in force in 
some other European Union countries, in particular in Poland, Lithuania, the Czech Republic, and Slovakia (Banchuk, 2015).

\section{Conclusions}

The comparative analysis enabled to argue that the legal regulation of liability for financial offenses in the countries of the European Union and in Ukraine has a wide range of differences, such as:

- first, in contrast to the Ukrainian experience, offenses in the financial and other spheres in many EU countries are criminal acts that are subject to criminal laws, consequently, they entail criminal penalties; - second, in many EU countries, the regulations providing liability for financial offenses are actually "scattered" among the provisions of a large number of legal regulations, often leading to legal conflicts;

- third, the legislation of the European Union states, in some cases, establishes legal responsibility for such offenses in the financial sphere, which in our country today are not recognized as criminally/administratively punishable, or, according to the degree of their social danger, entail imposing considerably fewer sanctions than in Europe.

Therefore, the analysis enabled to conclude that the mechanism of the legal regulation of liability for financial offenses in Ukraine is more improved than in European countries. Primarily, in our country, a strict codification of financial offenses exists. The differentiation of these offenses into administrative delinquents and criminal offenses is also positive because it enables to impose milder state sanctions on those acts that do not pose a significant social danger.

Nevertheless, the foreign experience of the legal regulation of liability for financial offenses should be analysed and applied to reveal outdated legal regulations and gaps in the national system of response options to financial offenses in order to overcome and correct these negative aspects.

\section{References:}

Melnyk, R.S. (2010). Administratyvno-hospodarske pravo yak strukturnyi element systemy administratyvnoho prava: zarubizhnyi dosvid ta natsionalni osoblyvosti [Administrative and commercial law as a structural element of the system of administrative law: Foreign experience and national features]. Pravo i bezpeka [Law and Safety], 2 (34), 55-59. (in Ukrainian) Busel, V. T. (2005). Velykyi tlumachnyi slovnyk suchasnoi ukrainskoi movy [Great explanatory dictionary of modern Ukrainian language]. K., Irpin: PTF Perun. (in Ukrainian)

Slovar russkogo literaturnogo yazyka [Dictionary of Russian literary language]. (1958). (Vol. 8). M.: Publishing House of the Academy of Sciences of the USSR. (in Russian)

Illicheva, L. F., Fedoseev, P. N. (Eds.). (1983). Filosofskii entsiklopedicheskii slovar [Philosophical encyclopedic dictionary]. M.: Sov. Encyclopedia. (in Russian)

Popov, S. V. (2001). Uvolnenie rabotnikov organov vnutrennikh del za narushenie distsipliny i zakonnosti [Dismissal of employees of Internal Affairs Bodies for violation of discipline and legality] (Dissertation). Kharkov: University of Internal Affairs. (in Russian)

Shemshuchenko, Yu. S. (1998). Yurydychna entsyklopediia [Judicial encyclopedia]. In 6 Vols. (Vol. 1: A - H). K.: Ukr. Entsyklopediia. (in Ukrainian)

Bilodid, I. K. (1976). Slovnyk ukrainskoi movy [Ukrainian language dictionary]. (Vol. 7). Kyiv: Naukova dumka. (in Ukrainian)

Skakun, O. F. (2010). Teoriia derzhavy i prava: pidruchnyk [Theory of State and Law: Teaching manual] (2nd ed.). K.: Alerta, CST; ZUL. (in Ukrainian)

Marchuk, V. P. (Ed.). (2003). Slovnychok yurydychnykh terminiv: navch. posib [Dictionary of legal terms: Teaching manual]. K.: MAUP. (in Ukrainian)

Volynka, K. H. (2003). Teoriia derzhavy i prava: pidruchnyk [Theory of State and Law: Teaching manual]. K.: MAUP. (in Ukrainian)

Bedniakova, N. V. (2006). Pravovye problemy materialnoi otvetstvennosti rabotodatelia [Legal problems of employer material liability] (Dissertation). Moscow. (in Russian)

Marchenko, M. N. (2004). Teoriia gosudarstva i prava: uchebnik [Theory of State and Law: Teaching manual] (2nd ed.). M.: TK Velbi, Publishing House Avenue. (in Russian)

Podorozhnii, Ye. Yu.(2016). Osoblyvostiyurydychnoividpovidalnostiutrudovomu praviUkrainy [Features oflegal responsibility in labor law of Ukraine] (Dissertation). Kharkiv: Kharkiv National University of Internal Affairs. (in Ukrainian)

Orliuk, O. P. (2010). Finansove pravo. Akademichnyi kurs: pidruchnyk [Financial law. Academic course: Teaching manual]. K.: Yurinkom Inter.

Romaniuk, I. I. (2013). Yurydychna vidpovidalnist za pravoporushennia u haluzi finansovoho prava, yak umova zmitsnennia finansovoi bezpeky derzhavy [Legal liability for offenses in the field of financial law as a condition for strengthening financial security of the state]. Naukovi zapysky Lvivskoho universytetu biznesu ta prava [Scientific Notes of Lviv University of Business and Law], 11, 175-178. (in Ukrainian)

Kodeks Ukrainy pro administratyvni pravoporushennia [Code of Ukraine on Administrative Offenses] (no. 8073-X of December 07, 1984). Vidomosti Verkhovnoii Rady URSR [Bulletin of the Verkhovna Rada of the USSR], 51, 1122. (in Ukrainian) 
Podatkovyi kodeks Ukrainy [The Tax Code of Ukraine] (no. 2755-VI of December 2, 2010). Vidomosti Verkhovnoii Rady Ukrainy [Bulletin of the Verkhovna Rada of Ukraine], 13, 13-14, 15-16, 17, 556. (2011). (in Ukrainian) Kryminalnyi kodeks Ukrainy [Criminal Code of Ukraine] (Code, Law no. 3441-III of 05.04.2001). Vidomosti Verkhovnoii Rady Ukrainy [Bulletin of the Verkhovna Rada of Ukraine], 25, 131. (in Ukrainian)

Moskalenko, N. V. (2014). Dosvid SSHA shchodo pobudovy systemy zapobihannia ta protydii lehalizatsii dokhodiv, otrymanykh zlochynnym shliakhom [US experience in establishing a system for preventing and combating the legalization of income derived from crime]. Finansy, uchet, banky [Finances, Accounting, Banks], 1(20), 209-214. (in Ukrainian)

Dranchenko, H. H. (2004). Zahalni zasady kryminalnoi vidpovidalnosti za podatkovi zlochyny za zakonodavstvom SShA [General principles of criminal liability for tax crimes under US law]. Aktualni problemy derzhavy i prava [Current Problems of State and Law], 889-896. (in Ukrainian)

Kamenskyi, D. V. (2011). Podatkova optymizatsiia ta podatkove ukhylennia u SShA: osoblyvosti vidmezhuvannia [Tax optimization and tax evasion in the United States: Features of delimitation]. Naukovyi visnyk mizhnarodnoho humanitarnoho universytetu [Scientific Bulletin of the International Humanitarian University], 2, 176-180. (in Ukrainian)

Fiscal Code of Germany in the version promulgated on 1 October 2002. Federal Law Gazette [Bundesgesetzblatt], I, 3866 (2003).

Criminal Code in the version promulgated on 13 November 1998, last amended by Article 3 of the Law of 2 October 2009. Federal Law Gazette I p. 3214. Federal Law Gazette [Bundesgesetzblatt], I, 3322.

Kryminalnyi kodeks FRN [Criminal Code of the Federal Republic of Germany] (Trans. from German). (2001). (A. V. Serebrenikova, Trans.). M.: Zertsalo-M. (in Russian)

Yermolova, N. Ye., Serebrenikova, A. V. (2008). Kryminalne pravo zarubizhnykh krain [Criminal law of foreign countries]. M.: Zertsalo-M. (in Ukrainian)

Vaskevich, K. Pravovoe regulirovanie otvetstvennosti za narushenie nalogovogo zakonodatelstva v FRG [Legal regulation of liability for violation of tax laws in Germany]. Gosudarstvennaia sluzhba [Public Service], 2(94). Retrieved from: http://pa-journal.igsu.ru/articles/r46/446/\#_ftn2 (in Russian)

Gesetz uber das Aufspuren von Gewinnen aus schweren Straftaten - Geldwachegesetz (Bundesministerium der Justiz). Retrieved from: http://bundesrecht.juris.de/bundesrecht/gwg/inhalt.html

Symovian, S. V. (2011). Dosvid Nimechchyny shchodo pravovoho rehuliuvannia problemy protydii lehalizatsii zlochynnykh dokhodiv [German experience in legal regulation of the anti-money laundering]. Forum prava [Legal Forum], 1, 904-908. (in Ukrainian)

Esakov, A. A., Krylova, N. E., Serebrennikova, A. V. (2009). Ugolovnoie pravo zarubezhnykh stran [Criminal Law of Foreign Countries]. M. (in Russian)

Kozochkin, I. D. (Ed.). (2001). Ugolovnoe zakonodatelstvo zarubezhnykh gosudarstv. Obshchaia chast [Criminal legislation of foreign countries. General part] (pp. 255-259). M.: A. S. Griboiedov Institute of International Law and Economics. (in Russian)

Salkazanov, A. E. (2017). Sravnitelno-pravovoi analiz ugolovnoi otvetstvennosti za neuplatu v biudzhety Rossii i Yevropy [Comparative legal analysis of criminal liability for non-payment to the budgets of Russia and Europe]. Yuridicheskie issledovaniia [Legal Research], 1, 105-115. (in Russian)

Mezentseva, I. Ye. (2002). Kryminalno-pravovi i kryminolohichni aspekty lehalizatsii hroshovykh koshtiv ta inshoho maina, zdobutykh zlochynnym shliakhom [Criminal legal and criminological aspects of legalization of monetary or other assets obtained by criminal means] (Dissertation). Kharkiv: Kharkiv National University of Internal Affairs. (in Ukrainian)

Romanko, P. S. Protydiia lehalizatsii (vidmyvanniu) dokhodiv oderzhanykh zlochynnym shliakhom: porivnialnyi analiz zakonodavstva Yevropeyskykh krayin ta SShA [Counteraction to legalization (laundering) of proceeds from crime: A comparative analysis of the legislation of European countries and the USA]. Naukovyi visnyk Uzhhorodskoho natsionalnoho universytetu [Scientific Bulletin of Uzhgorod National University], 28(3), 106-110. (in Ukrainian)

Kryminalnyi kodeks Ispanii [Criminal Code of Spain]. Retrieved from: http://ugolovnykodeks.ru/2011/11/ ugolovnyj-kodeks-ispanii/

Klochko, V. M. (2013). Inozemnyi dosvid kryminalno-pravovoi okhorony rynku tsinnykh paperiv [Foreign experience of criminal law protection of the securities market]. Naukovyi visnyk Natsionalnoi akademii vnutrishnikh sprav [Scientific Bulletin of the National Academy of Internal Affairs], 4, 275-282. (in Ukrainian)

Kokorev, V. G. (2012). Ekonomicheskie prestupleniia v ugolovnom kodekse Ispanii [Economic crimes in the Criminal Code of Spain]. Sotsialno-ekonomicheskie yavleniia i protsessy [Socio-Economic Phenomena and Processes], 12(046), 373-380. (in Russian)

Talan, M.V. (2007). Zakonodatelstvo yevropeyskikh gosudarstv ob Ekonomicheskikh prestupleniiakh [The legislation of European countries on economic crimes]. Uchenye zapiski Kazanskogo gosudarstvennogo universiteta [Scientific notes of Kazan State University], 149(6), 261-272. (in Russian)

Kodeks Latvii pro administratyvni pravoporushennia [Latvian Code of Administrative Offenses] (Law of December 7, 1984). Retrieved from: https://likumi.lv/ta/en/en/id/89648

Banchuk, O.A. (2015). Zakonodavstvo pro administratyvni delikty Yevropeyskykh derzhav: zahalna kharakterystyka [Legislation on administrative delicts in European countries: General characteristics]. Administratyvne pravo i protses [Administrative Law and Process], 1(11), 96-110. (in Ukrainian) 